\title{
Implications of Poverty on Children Readiness to Learn
}

\author{
P. Ramya, K. Ramamoorthi
}

\begin{abstract}
In this current era education is much needed one to survive in this world. Lots of implications are there to affect the learning of children. Due to poverty people are not able to fulfil even their basic needs. The people below poverty line focus only for fulfilling their daily needs rather than concentrating on their children's education. Since the children do not get the required materials and facilities for studythey lose interest for study. Hence this leads to dropout of students from school. During this time it is necessary to know the reasons as well as the readiness of children to study. Therefore the researcher is making an attempt to analyze through this study the researcher is making an attempt analyze the implications of poverty on children readiness to learn. For this study purpose the researcher has taken into consideration the Madurai slum area. Interview schedule is used for the data collection and around thirty samples were taken for this purpose. Through this study the researcher is trying to analyze the causes of situation which create more of dropout among the children social demographic details, implications of poverty on children readiness to learn, and what is their need to overcome. The researcher has also come up with suitable suggestion for decreasing the dropout rate of schoolchildren.
\end{abstract}

\section{INTRODUCTION}

Poverty is regarded as one of the most important factor affecting the people of a developing country. There are about seven type of poverty in which economical poverty is the most affecting factor on children in their studies. But in this study explain the how economical poverty affect the children study. Poverty is the being state of tremendously poor. People who are economically backward will not be even able to fulfil their basic needs. Due to poverty people below the poverty line face lot of issues like social inequality, discrimination etc. When people below the poverty line find difficult even to fulfill the basic needs they seldom give importance to the education of children. Slum areas are the most affectedplaces with regards to dropout of children from school the researcher through this study is trying to find the interest of students towards studies due to their poverty.

\section{REVIEW OFLITERATURE}

The aim of the study is to Implications of poverty on Children Readiness to Learn. There has been lot of studies related to poverty on children learn. According to Shadreck (2013) a low socio-economic family background is a major cause of the phenomenon of dropping out with students dropping out due to poverty and financial constraints.

Revised Manuscript Received on December 16, 2019

Ms. P Ramya, Assistant Professor, Kalasalingam Academy of Research and Education, Srivilliputhur, Tamil Nadu, India

Mr K. Ramamoorthi, Social Work Trainee, Department of Social Work, Kalasalingam Academy of Research and Education, Srivilliputhur, Tamil Nadu, India.
The study has also revealed that certain school conditions can lead to premature school dropout. Thus, schools appear to influence dropout behaviour through their organization, their structure and their school climate, policies and possibly practically push students towards a gradual exit (fade-out) or to leave school (push-out). Maranoorand om ashekharappappa (2012) categorized personal factors, family factors, school factors and socio- economic factors. Personal factors included self ill heath, not interested in study, physical inability, retired minded etc. Family factor plays an important role in female school dropouts especially. Its features involvements in domestic chores, sickness in the family, looks after for siblings, parents' disinterest in girls' education etc. School also a significant factor for school dropouts. Its features lack offacilities, teacher didn't teach properly, fears of teacher, long distance of school etc. Socioeconomic factors are also playing a very important role in school dropouts especially in male dropouts. Its features lack of money, death of father, early marriage, negative attitude of society etc. According to Naseer Ahmad Salfi and Khan (2011) findings of the study it seems that on an individual basis, the reasons for dropping out vary, but generally there are two main categories of factors that lead to dropping out students at primary level. These are out-of-school factors and in-school factors. Out-of- school factors are parent's poverty, parent's lack of motivation and understanding of value education, opportunity cost to the parents by sending the child to school, migration of parents and long distance of schools from homes. While in school factors include lack of facilities in schools; defective textbooks and curriculum which is beyond the comprehension level of students; and harsh attitude of the teachers with students. According to Rumberger's (2011) finding that having friends who engage in criminal behaviour or are part of gangs' increases the odds of dropping out. We also find that, in general, from the location attributes, median family income and industry structure influence dropout rates, and they have different magnitudes and directions in rural and urban areas. Overall, differences in family- level conditions have far more predictive power in determining graduation than geographicattributes.

\section{NEED AND SIGNIFICANCE OF THE STUDY}

School dropout, is one who withdraws before completing a course of instruction (Wikipedia). According to a study by the national centre of Education statistics students with low family incomes have the highest dropout rates at $9.4 \%$. 37000 school dropouts in Tamil Nadu in June 2016 survey, Survey was conducted by Deccan ChronicleA. Ragu Raman. Hence due to all

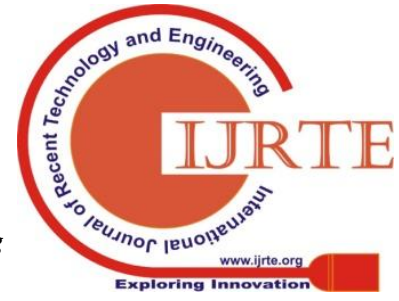


these reasons the researcher is trying to analyze the poverty on children's readiness to learn and what are the causes affect their learning.

\section{OBJECTIVES}

The researcher is trying to study Implications of Poverty on Children Readiness to Learn. One of theobjectives of the study is to study the socio demographic details of the respondents. The researcher is also trying to understand the causes for dropout of the children from school. Another major objective is to give suitable suggestion in order to decrease dropout of children.

\section{METHOD OFSTUDY}

In this research the researcher has used both qualitative and quantitative method of study. And Survey was used for data collection. The researcher used interview schedule for data collection. The study conducted in Madurai JeevaNagar slum. The total student's population in that particular areais 500, Out of this population the researcher, the researcher has taken thirty samples by using Simple RandomSampling.

\section{RESULT ANDDISCUSSION}

The study is conducted mainly with the purpose of finding implications of poverty on children readiness to learn. The researcher conducted a survey question regarding the family members of respondents. 63.3 percent of the respondents having 5 members in their family, 20 percent of the respondents having 4 members in their family, 13.3 percent of the respondents having 6 members in their family and another 3.3 percent of the respondents having 3 members in their family. Hence it can be summarized that most oftherespondents are having five family members as dependents on income earners. The next survey question was regarding bread winners of the family. 50 percent of family has 2 working members, 36.7 percent of the family has a 1 working member in their family and 6.7 percent of the family have 4 working members in their family. Hence it can be summarised that the half of the respondent's family have a 2 working members in their family. The researcher framed a survey questionto know the earners of the family. In this question the researcher trying to find whether the student's family have enough income to run the family. 50 percent of the respondent's family are having 5000- 10000 as their family income, 40 percent of respondents family having 10000-15000 monthly income and 10 percent of respondents family having 15000-20000 monthly income.Hence it can be summarised that half of the respondents family income is 5000- 10000. The researcher conducted a survey question regarding how they get education support. In this question the researcher trying to find whether the students get educational support from family. 96.7 percent of the respondents' get education support from their family and 3.3 percent of therespondent's are self employed for their education support.Hence it can be summarised that most of the respondents get educational support from their family. In this question the researcher trying to find whether they have educational support from relatives. 90 percent of the respondents are didn't get any support from their relatives for their studies and another 10 percent of respondents get educational support from their relatives.Hence it can be summarised that the most of the respondents didn't get any education support from relatives. The next question was regarding the time spent by the respondent per day for the study. 26.7 percent of respondents are spent 2-4 hour for their studies in home and 23.3 percent of respondents are spent 0-1 hours for their studies in home. Hence it can be summarised that the most of the respondents spent 2-4 hours to study in a day. The researcher questioned about distance between school and home. In this question the researcher trying to find how much kilo meters students travel to reach the school. 60 percent of the respondents travel to school less than 1 kilometre. 23.3 percent of respondents travel to school more than 2 - 4 kilo meters. 10 percent of respondents are travel for school more than $4-5$ kilo meters. 6.7 percent of respondents travel to school more than 5 kilo meters in a day for education. Hence it can be summarised that more than half of the respondents are travel less than 1 kilo meter to school. The next question was regarding the mode of transport to school. 66.7 percent of respondents went to school by walking because schools are near their homes. 33.3 respondents are using government/private vehicle for going to school because of long distance between school and home. Hence it can be summarised that more than half of the respondents are going to school by walking. The researcher framed a survey question regarding how teachers treat the students in school. In this question the researcher trying to find whether the teachers are treating the students well. 66.7 percentrespondentssaid teachers treat very nicely inside the school and 33.3 percent of respondents said teachers treat the students neutrally inside the school.Hence it can be summarised that the more than half of the respondents feel that teachers treat in very good manner. The researcher conducted a survey question was regarding the income sufficient for family expenses. In this question the researcher trying to find whether the student's family have enough income for their family expenses. As per the thirty percent respondents answers based 63.3 percent of respondents family face money problem due to insufficient income and 36.7 percent of respondents family have sufficient income for face their family needs.Hence it can be summarised that the more than half of the respondents family face insufficient income for their family expenses. The researcher asked survey question was regarding feel financial problem while studying. In this question the researcher trying to find whether the students are feel financial problem while studying. 53.3 percent of the respondents feel money problem in their family while studying and the 46.7 percent of respondents are didn't feel money problem while studying. Hence it can be summarised that the more than half of the respondents are feel financial problem while studying. The researcher framed question to know if the students have enough study materials and Dress. Through this question the researcher trying to find whether the students have enough studies materials and dress.

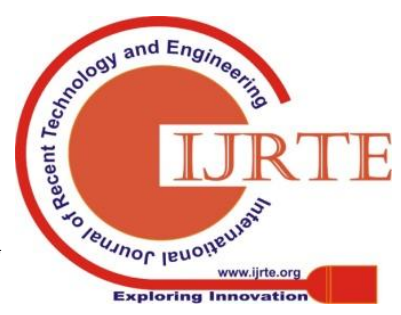


100 percent ofthe respondents feel that they get enough study materials and dress for their studies.Hence it can be summarised all the respondents have enough study materials and dress. Another question was asked to respondents whether they like to attend school. In this question the researcher trying to find whether the students like or didn't like their school. 73.3 percent of the respondents are like their school for study and another 26.7 percent of the respondents are didn't like their school.Hence it can be summarised that the more than half of the respondents like their school. The researcher conducted a survey question regarding attending the class regularly. In this question the researcher trying to find whether the students attend their class regularly or not.86.7 percent of the respondents are attend their school regularly without being absent and another 13.3 percent of the respondents are didn't attend their classes regularly they make lots of absents. Hence it can be summarised that the most of the respondents attend the class regularly. The next survey question was regarding the good relationship among student. In this question the researcher trying to find whether the students have a good relationship with the school students. 86.7 percent of respondents said they have good relationship with others, lots of friends are there in their circle and another 13.3 percent of the respondents are said not have good relationship among students due to joining new school environment. The survey question was regarding the additional expenses of the student. Hence it can be summarised that the most of therespondentshave a good relationship with their school students. In this question the researcher is trying to find whether the students themselves are able to meet the extra expenses. 93.3 percent of the respondents said they cannot meet additional expenses for their studies they totally depend on their family for study, and 6.7 percent of respondents said they can meet additional expenses for their study by doing part time jobs. Hence it can be summarised that most of the respondents are not able meet additional expenses. The researcher conducted a survey question regarding the interest in subjects of the student in learning them. In this question the researcher trying to find whether the students are feeling interest to study their subjects. 80 percent of the respondents said the subjects are interesting to study and 20 percent of the respondents are said the subjects are not interest to study. Hence it can be summarised that the most of the respondents are feel interest to study their subjects. At this study can be summarise most of the respondents are having five family members. Half of the respondent's family have 2 working members in their family. Half of the respondent's family income is 5000-10000. The most of the respondents get educational support from their family. The respondents are didn't get any education support from relatives. The most of the respondents that is 26.7 percent are spent 2-4 hours to study in a day. ore than half of the respondents are travel less than 1 kilo meter to school due to school are nearing the home. More than half of the respondents went to school through walking. More than half of the respondents answer is teachers are treatin very good manner. More than half of the respondent's family face insufficient income for their family expenses. More than half of the respondents are feel financial problem while studying. All of the respondents have study materials and dress. More than half of the respondents like their school. Most of the respondents attend the class regularly. The most of the respondents have a good relationship with their school students. Most of the respondents are not able to meet additional expenses. Most of the respondents feel interested to study theirsubjects.

\section{CONCLUSION}

The study has been taken up to find the implications of poverty on children readiness to learn. This study has been conducted in Madurai slum area. Due to poverty most of the children are sent to government schools by the parents. Through this research, researcher collected data about socio demographic details, relationship between school and student, and suggestion from the respondents to reduce the dropouts in school. The main problem faced by these children is that extra fees is been collected in the name of book fees. Due to extra fees children are not able to afford the extra cost hence parents are not willing to sent children to school, due to financial problem. The children also not happy about infrastructure facility provided in the school. Most of the respondents are like the subjects taught by the teachers and feel subjects are interesting. If government gives good infrastructure ingovernmentschools and provide scholarships to the children, there would be increase in interest of children to study and the parents also will be happy to send their children to schools. The government should also take necessary steps to educate the people regarding the importance of Educating children and also the benefits available for education.

\section{REFERENCES}

1. Carneiro, P., and Heckman, J. (2002). "The evidence on credit constraints in post-secondary schooling." Economic Journal, 112:705734

2. Dropout at Primary Level in Pakistan: An Empirical Study." International Journal of Humanities and Social Science, 1(12):167-172.

3. Ellickson, P.L., Bui, K., Bell, R.M., and McGuigan, K. (1998). "Does early drug use increase the risk of dropping out of highschool?"

4. Journal of Drug Issues, 28: 357-380

5. Fagan, J., and Pabon, E. (1990). "Contributions of delinquency and substance use to school dropout among inner-city youth." Youth and Society, 21:306-354

6. Garnier, H.E., Stein, J.A., and Jacobs,

7. J.K. (1997). "The process of dropping out of high school: A 19 year perspective." American Educational Research Journal, 34: 395-419.

8. Jordan, W., Lara, J., and McPartland, J. (1996). "Exploring the causes of early dropout among race, ethnic, and gender group." Youth and Society, 28:62-94.

9. Maranoor, R.S., and Somashekharappappa, C.A. (2012). "The problems of the school dropout in North Karnataka" - A Sociological Study. Indian Journal of Applied Research,1(12).

10. Rumberger, R.W. (2011). "Dropping out: Why students dropout of high school and what can be done about it. Cambridge, MA: Harvard University Press. See it Jeffrey L. Jordon and GentiKostandini. Rural and Urban High School Dropout Rates: Are they different? Journal of Research in Rural Education,27(12)

11. Naseer Ahmad Salfi, A.H., andKhan, T.M. (2011). "Causes of Students' Rumberger, R.W. (1983). "Dropping out of high school: The influence of race, sex and family background." American Educational Research Journal, 20: 199- 220. 
12. Sabates, R., Hossain, A., andLewin, K.M. (2010). "School Dropout in Bangladesh: New In sights from Longitudinal Evidence- Create pathways to access." Research Monograph No.49: 4- 16.

13. Sachs, Jeffrey (2005): The End of Poverty - How We Can Make it Happen in Our Lifetime, Penguin Books, London. Sambandan, V S (2013): "Bhagwati, Sen and India's fight against poverty", The Hindu. Sen, Amartya \&Drèze, Jean (2003): The Omnibus - Poverty and Famines; Social Opportunity, Oxford University Press, New Delhi.

14. Sen, Amartya (1981): Poverty and Famines: An Essay on Entitlement and Deprivation, Oxford University Press, NewYork. Singh, Annapurna (2013):"Problems in estimating poverty", www.deccanherald.com/content/197219/pr oblems-estimatingpoverty.html,August 2013.

15. Shah, Anup (2011): "Causes of Hunger are related to Poverty",http://www.globalissues.org/,

16. Visaria, Pravin (1992): "Data Base on Poverty in India: An Exploration", in Kadekodi, G K and Murty, G V S N (eds.), Poverty in India: Data Base Issues, Vikas Publishing House Pvt Ltd, New Delhi,pp.39-55.

\section{AUTHORS PROFILE}

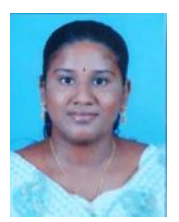

Ms Ramya. $\mathrm{P}$ is an MSW graduate specialized in Human Resource Management. She is associated with Kalasalingam Academy of Research and Education as Assistant Professor in Department of Social Work. She has published articles related to social cause in four international journals and also published articles in both national and international journals.

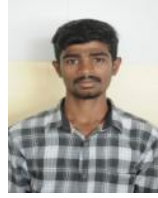

Mr K. Ramamoorthi, is a Social Work Trainee associated with Kalasalingam Academy of Research and Education in Department of Social Work. He has published papers in both International and national conferences. 